\title{
Effect of protein supplementation and urea treatment on utilization of maize stover by Red Maasai sheep
}

\author{
T.A. Woyengo, C.K. Gachuiri" ${ }^{\#}$ R.G. Wahome and P.N. Mbugua \\ Department of Animal Production, University of Nairobi, P.O. Box 29053, Nairobi, Kenya
}

\begin{abstract}
Six Red Maasai sheep were used to investigate the effects of urea treatment and cotton seed cake supplementation of maize stover on intake, digestibility and rumen fermentation parameters. The basal feeds were Rhodes grass (Chloris gayana) hay $(\mathrm{H})$, untreated maize (Zea mays) stover (US) and treated maize stover (TS), each of which was supplemented with $100 \mathrm{~g}$ of cotton seed cake (CSC) to make H+CSC, US+CSC and TS+CSC. These were offered over four feeding periods in a completely randomized block design, with periods serving as blocks. Hay and US treatments had similar intakes, digestibility, ruminal fluid volatile fatty acid (VFA) concentrations and $\mathrm{pH}$. Urea treatment of the stover increased the digestibility of dry matter (DM), organic matter (OM), crude protein (CP), neutral detergent fibre (NDF) and cellulose as well as the rumen ammonia nitrogen (AN) concentration. Cotton seed cake supplementation increased DM, OM and CP digestibility in US from 445 to $614 \mathrm{~g} / \mathrm{kg}, 475$ to $633 \mathrm{~g} / \mathrm{kg}$ and 308 to $604 \mathrm{~g} / \mathrm{kg}$, respectively and VFA concentration in the rumen from 31 to $196 \mathrm{mmol} / \mathrm{L}$. Supplementation of treated stover, increased the AN concentration (137 vs. $234 \mathrm{mg} / \mathrm{l})$ rumen in the rumen content with no effect on nutrient digestibility and VFA concentration. The $\mathrm{pH}$ of the ruminal content for the diets ranged from 6.83 to 7.12. The trends of rumen AN and VFA for supplemented diets showed a gradual rise to a maximum three hours post-feeding, followed by a decrease in their respective concentrations. It was concluded that urea treatment and CSC supplementation of stover increased its utilization but supplementation of treated stover with CSC was not effective.
\end{abstract}

Keywords: Sheep, ruminal fermentation, maize stover, urea treatment

\#Corresponding author. E-mail address: gachuiri@uonbi.ac.ke

\section{Introduction}

The major constraint to livestock production in sub-Saharan Africa is poor nutrition due to scarcity of feeds (Osuji et al., 1995; Omore et al., 1996; Methu, 1998). Maize stover, which is available in large quantities, can play a role in filling this gap. However, it is of low nutritive value due to its low digestibility and its failure to provide the rumen microorganisms and the host animal with all the nutrients required (Preston, 1986; Methu, 1998; Undi et al., 2001). The nutritive value of crop residues such as maize stover, has been increased by alkali treatment and/or nitrogen $(\mathrm{N})$ supplementation (Alayu, 1987; Cronje \& Weites, 1990; Oosting, 1993; Preston, 1995; Chandrasekharaiah et al., 1996). Urea is the preferred alkali for treatment due to its low cost and ease of handling (Kiangi \& Kategile, 1981; Sahnoune et al., 1991) and the extra $\mathrm{N}$ it supplies increases the crude protein (CP) concentration of crop residues (McDonald et al., 1995). Supplementation of crop residues with true protein rather than non-protein nitrogen (NPN) is more desirable as it supplies both rumen degradable and non-degradable protein (Oosting, 1993). Cronje \& Weites (1990) supplemented urea sprayed wheat straw with different amounts of cotton seed cake and observed a marked increase in straw intake, feed conversion, average daily gain and wool growth in sheep. Oil seed cakes have a high potential for non-degradable protein due to the effect of heat during processing (Leng, 1999).

Although several studies reported improved nutritive value of stover due to alkali treatment and protein supplementation, most studies have concentrated on determining intake and digestibility. There is, however, little work done on changes in the ruminal environment. This study compared the utilization of Rhodes grass hay, maize stover and urea treated maize stover by Red Maasai sheep. In addition, the study determined the effect of supplementation of basal feeds with cotton seed cake on intake, digestibility and ruminal fermentation parameters. 


\section{Materials and Methods}

Six experimental diets consisting of three basal feeds were fed to six one-year old rumen fistulated male Red Maasai sheep (body weight $33.3 \pm 3 \mathrm{~kg}$ ). The three basal feeds were Rhodes grass (Chloris gayana) hay as control (H), untreated maize (Zea mays) stover (US) and urea treated maize stover (TS). Each of the basal feeds was fed alone or supplemented with cotton seed cake (CSC) to make the six diets, viz. H, $\mathrm{H}+\mathrm{CSC}$, US, US+CSC, TS and TS+CSC. The animals were placed in metabolism crates to enable collection of ruminal fluid samples and faeces. They were adapted to the crates before the initiation of the experiment.

Maize stover and hay were prepared by chopping them to an average length of $2.5 \mathrm{~cm}$. Urea treatment was carried out by soaking chopped maize stover in a $4 \% \mathrm{w} / \mathrm{v}$ fertilizer grade urea $(46 \% \mathrm{~N})$ solution in a drum until wet. The wet stover was placed on a wire mesh on top of another drum using a hayfork, and allowed to drip for 20 minutes. The stover was then transferred into polythene tubes, which were immediately sealed (airtight) using sisal strings to prevent the escape of ammonia. The treatment continued for a period of 30 days at ambient temperatures after which the tubes were opened and each day's requirements scooped out and aerated (indoors) for 48 hours prior to feeding to allow effusion of ammonia.

The experiment consisted of four, 17-day feeding periods. The experiment was a randomized complete block design with periods as blocks and the six diets as treatments. The animals were randomly allocated to the six diets during each feeding period. Before sampling during each feeding period experimental animals were adapted to their respective basal diet for a period of 14 days.

During the experimental period the sheep were fed the basal feeds on an ad libitum basis. They were fed twice daily, at 08:00 and at 14:00. Mineral blocks were made available ad libitum to each sheep. Water was offered twice daily at 12:00 and 18:00. Cotton seed cake was offered at a rate of $0.1 \mathrm{~kg} / \mathrm{sheep} / \mathrm{day}$. It was given in two equal portions at 08:00 and 14:00 before offering fresh basal feeds. The animals consumed all the offered supplement.

During the last seven days of each experimental period voluntary dry matter intake was determined by monitoring the amount of feed offered and the refusals on a daily basis. Samples of the treated stover offered, were dried in an oven at $60{ }^{\circ} \mathrm{C}$ for DM determination. Apparent digestibility was determined by means of the total collection method. The faeces from each collection bucket were collected twice daily at 08:00 and 17:00, pooled and weighed. A sample of $10 \%$ faecal output was dried in an oven at $60{ }^{\circ} \mathrm{C}$ for DM determination. Daily samples of feedstuffs offered and faeces were obtained and stored for chemical analysis.

At the end of the four feeding periods, dried samples of the feedstuffs were ground through a $2 \mathrm{~mm}$ screen and pooled for each type of feedstuff and each period. Dried samples of faecal material were ground and pooled for each sheep and each period. The pooled samples were then analysed for dry matter (DM), organic matter (OM), CP and ash, following the methods as described by AOAC (1998), and neutral detergent fibre (NDF), hemicellulose, cellulose and lignin according to the methods of Goering \&Van Soest (1970).

During the last two days of each feeding period, approximately $35 \mathrm{~mL}$ of ruminal fluid were obtained from each animal at 0, 2, 4 and 6 hours after morning feeding. The samples were strained through four layers of cheesecloth and $\mathrm{pH}$ determined using a portable $\mathrm{pH}$ meter. Ten $\mathrm{mL}$ of each sample were frozen and stored for later determination of concentrations and molar proportions of individual volatile fatty acids (VFA). The remaining $25 \mathrm{~mL}$ were acidified with a few drops of concentrated sulphuric acid to give a $\mathrm{pH}$ below 3, frozen and stored for later analysis of ammonia-nitrogen (AN) concentration. Concentrations and molar proportions of VFA were determined by gas liquid chromatography (GLC) (Preston, 1995) and AN concentration by steam distillation procedure (ILRI, 1997).

The model that best described the trends of rumen parameters was fitted to VFA and AN concentration data. The model was: $Y_{i}=a+b_{1} t_{i}+b_{2} t_{i}^{2}$, where $Y_{i}=i^{\text {th }}$ observation at $i^{\text {th }}$ time of ruminal sampling, $a$ is the intercept, $b_{1}$ and $b_{2}$ are parameters describing the trend. The parameters $a, b_{1}$ and $b_{2}$ together with data for chemical composition of feedstuffs, intake and digestibility were subjected to analysis of variance by the model: $\mathrm{Y}_{\mathrm{ijk}}=\mu+$ period $_{\mathrm{i}}+$ diet $_{\mathrm{j}}+$ error $_{\mathrm{ijk}}$ using Stat View (1986). Means were separated using least significant differences (LSD). 


\section{Results and Discussion}

The chemical composition of $\mathrm{H}$, US, and TS are shown in Table 1. Untreated maize stover contained a higher level of $\mathrm{CP}$ and a lower level of lignin than $\mathrm{H}(\mathrm{P}<0.05)$, but they were similar in NDF, hemicellulose and cellulose content $(\mathrm{P}>0.05)$. Urea treated maize stover had higher $\mathrm{CP}$ and lignin and lower NDF and hemicellulose concentrations then US ( $\mathrm{P}<0.05$ ). The CP content of CSC was $326 \mathrm{~g} / \mathrm{kg}$ DM.

Table 1 Mean ( \pm s.d.) chemical composition (g/kg DM) of hay (H), untreated maize stover (US) and urea treated maize stover (TS)

\begin{tabular}{lccc}
\hline \multicolumn{1}{c}{ Feedstuff } & $\mathrm{H}$ & $\mathrm{US}$ & TS \\
\hline & & & \\
Dry matter (DM) (g/kg) & $911 \pm 19$ & $899 \pm 18$ & $472 \pm 20$ \\
& & & \\
Nutrient composition (g/kg DM) & $907 \pm 9^{\mathrm{ab}}$ & $911 \pm 4^{\mathrm{b}}$ \\
Organic matter & $898 \pm 3.5^{\mathrm{a}}$ & $71 \pm 12^{\mathrm{b}}$ & $90 \pm 15^{\mathrm{c}}$ \\
Crude protein & $43 \pm 6^{\mathrm{a}}$ & $824 \pm 42^{\mathrm{a}}$ & $743 \pm 40^{\mathrm{b}}$ \\
Neutral detergent fibre & $820 \pm 22^{\mathrm{a}}$ & $348 \pm 14^{\mathrm{a}}$ & $237 \pm 60^{\mathrm{b}}$ \\
Hemicellulose & $335 \pm 13^{\mathrm{a}}$ & $403 \pm 33^{\mathrm{a}}$ & $406 \pm 53^{\mathrm{a}}$ \\
Cellulose & $371 \pm 17^{\mathrm{a}}$ & $57 \pm 11^{\mathrm{b}}$ & $84 \pm 38^{\mathrm{a}}$ \\
\hline
\end{tabular}

${ }^{\mathrm{abc}}$ Values in row with similar superscripts do not differ $(\mathrm{P}>0.05)$.

Table 2 shows the DM intake and digestibility coefficients of DM, OM, CP, NDF, hemicellulose and cellulose for the six diets. The DM intakes did not differ between the diets ( $\mathrm{P}>0.05)$. However, intakes of supplemented diets tended to be higher. The DM intake varied from 1.1 to $2.1 \%$ of body weight. Undi et al. (2001) reported intakes in the order of $1.5 \%$ for stover and $2.5 \%$ for supplemented stover.

Table 2 Dry matter intake (DMI) and apparent digestibility (g/kg) of dry matter (DM), organic matter $(\mathrm{OM})$, crude protein $(\mathrm{CP})$, neutral detergent fibre (NDF), hemicellulose and cellulose for the six diets fed to sheep

\begin{tabular}{lccccccc}
\hline \multirow{2}{*}{ Item } & \multicolumn{9}{c}{ Diets } \\
\cline { 2 - 8 } & $\mathrm{H}$ & US & TS & H+CSC & US+CSC & TS+CSC & s.e.d. \\
\hline DMI (kg/d) & 0.37 & 0.44 & 0.53 & 0.69 & 0.67 & 0.53 & 0.18 \\
\multicolumn{1}{l}{ Apparent digestibility (g/kg DM) } & & & & & \\
DM & $468^{\mathrm{ab}}$ & $445^{\mathrm{a}}$ & $651^{\mathrm{c}}$ & $556^{\mathrm{abc}}$ & $614^{\mathrm{bc}}$ & $668^{\mathrm{c}}$ & 76 \\
OM & $488^{\mathrm{a}}$ & $475^{\mathrm{a}}$ & $676^{\mathrm{b}}$ & $576^{\mathrm{ab}}$ & $633^{\mathrm{b}}$ & $674^{\mathrm{b}}$ & 66 \\
CP & $289^{\mathrm{a}}$ & $308^{\mathrm{a}}$ & $473^{\mathrm{b}}$ & $623^{\mathrm{b}}$ & $604^{\mathrm{b}}$ & $563^{\mathrm{b}}$ & 76 \\
NDF & $465^{\mathrm{a}}$ & $477^{\mathrm{ab}}$ & $593^{\mathrm{c}}$ & $483^{\mathrm{a}}$ & $575^{\mathrm{bc}}$ & $643^{\mathrm{c}}$ & 54 \\
Hemicellulose & $413^{\mathrm{a}}$ & $574^{\mathrm{bc}}$ & $614^{\mathrm{bc}}$ & $505^{\mathrm{ab}}$ & $625^{\mathrm{bc}}$ & $648^{\mathrm{c}}$ & 63 \\
Cellulose & $544^{\mathrm{a}}$ & $489^{\mathrm{a}}$ & $657^{\mathrm{bc}}$ & $503^{\mathrm{a}}$ & $587^{\mathrm{ab}}$ & $698^{\mathrm{c}}$ & 51 \\
\hline
\end{tabular}

H - hay; US - untreated maize stover; TS - urea treated maize stover; H+CSC - H plus 0.1 kg cotton seed cake;

US+CSC - US plus $0.1 \mathrm{~kg}$ cotton seed cake; TS+CSC - TS plus $0.1 \mathrm{~kg}$ cotton seed cake

s.e.d. - standard error of differences of the means

abc Values in row with similar superscripts do not differ $(\mathrm{P}>0.05)$.

The US and $\mathrm{H}$ diets had similar DM digestibilities $(\mathrm{P}>0.05)$. Treatment of stover improved $(\mathrm{P}<$ 0.05 ) the DM, OM, CP, NDF and cellulose digestibility of the stover. Alkali treatment is reported to cause swelling of cell walls (which allows greater diffusion of cellulolytic enzymes), disruption of bonds between lignin and cell wall carbohydrates (which increases the availability of the carbohydrate for degradation by rumen microorganisms) and solubilisation of some of hemicellulose and CP (Theander, 1981; Oosting, 1993; Van Soest, 1994). In addition, urea treatment provides extra N, which increases rumen microbial activity (Van Soest, 1994) and hence increases digestibility (Tuen et al., 1991; Oliveros et al., 1993; Shashi-Saijpaul et al., 1996). 
Cotton seed cake supplementation improved $(\mathrm{P}<0.05)$ the apparent $\mathrm{CP}$ digestibility of the hay and untreated stover, the DM, OM and NDF digestibility of untreated stover, but did not influence the digestibility of the nutrients in treated stover. Digestion of feed by microorganisms in the rumen depends on the availability of $\mathrm{N}$ and fermentable organic matter (Ørskov \& Grubb, 1978). It is likely that the digestion of $\mathrm{H}$ was firstly limited by availability of fermentable OM due to a high lignin content. Availability of fermentable OM from CSC therefore marginally improved overall OM digestibility $(\mathrm{P}>0.05)$. Oosting (1993) fed sheep on wheat straw (with high lignin content of $75 \mathrm{~g} / \mathrm{kg}$ ) and similarly found that $\mathrm{N}$ supplementation did not increase the DM digestibility of the straw (372 vs. $360 \mathrm{~g} / \mathrm{kg}$ ). The higher digestibility of $\mathrm{CP}$ for $\mathrm{H}+\mathrm{CSC}$ compared with $\mathrm{H}(\mathrm{P}<0.05)$ was due to the higher digestibility of CP of CSC origin. The higher OM digestibility after supplementation of US with CSC was due to higher CP levels in US coupled with lower lignin level (compared to H). Butterworth \& Mosi (1986) and Alayu (1987) also reported increased digestibility of low quality roughages after protein supplementation. This increased digestibility could lead to higher productivity in terms of weight gain and wool growth as observed by Cronje \& Weites (1990) when they supplemented wheat straw with cotton seed cake.

The digestibility of nutrient components for TS was not improved by the CSC supplementation (P > 0.05). Rumen microbial activity had probably climaxed from $\mathrm{N}$ supplied by TS. It could be assumed that supplementation with CSC resulted in higher supply of $\mathrm{N}$ than required by the microbes. Capturing of AN to form new microbial protein requires a synchronized and sufficient energy release. Most likely the extra nitrogen was lost due to insufficient energy. Alayu (1987) reported a similar response to CSC supplementation, when he fed sheep on urea treated wheat straw. Responses to protein supplementation have been shown to depend on level of energy supplied in the diet (Cronje \& Weites, 1990).

The $\mathrm{pH}$ values and AN and VFA concentrations of ruminal fluid for the diets are presented in Table 3. The $\mathrm{pH}$ for the diets ranged from 6.83 to 7.12. Van Soest (1994) stated the $\mathrm{pH}$ range for optimal microbial activity as 6.2 to 7.2. The $\mathrm{pH}$ of the fluid for all the diets, though different $(\mathrm{P}<0.05)$, was within this range and did not fluctuate during the six hour period of monitoring after morning feeding $(\mathrm{P}>0.05)$.

Table 3 Average $\mathrm{pH}$, ammonia-nitrogen (AN) (mg/L) and volatile fatty acids (VFA) concentrations $(\mathrm{mmol} / \mathrm{L})$ of ruminal fluid for the different treatments

\begin{tabular}{cccccccc}
\hline Item & \multicolumn{9}{c}{ Diets } \\
\cline { 2 - 7 } & $\mathrm{H}$ & US & TS & H+CSC & US+CSC & TS+CSC & S.e.d. \\
\hline PH & $6.98^{\mathrm{abc}}$ & $7.11^{\mathrm{ab}}$ & $7.12^{\mathrm{a}}$ & $6.83^{\mathrm{c}}$ & $6.90^{\mathrm{bc}}$ & $6.84^{\mathrm{c}}$ & 0.1 \\
AN & $9^{\mathrm{a}}$ & $63^{\mathrm{b}}$ & $137^{\mathrm{c}}$ & $69^{\mathrm{b}}$ & $79^{\mathrm{b}}$ & $234^{\mathrm{d}}$ & 27 \\
VFA & $79^{\mathrm{ab}}$ & $31^{\mathrm{a}}$ & $76^{\mathrm{ab}}$ & $71^{\mathrm{ab}}$ & $196^{\mathrm{c}}$ & $142^{\mathrm{bc}}$ & 39 \\
\hline
\end{tabular}

H- hay; US - untreated maize stover; TS - urea treated maize stover; H+CSC - H plus 0.1 kg cotton seed cake; US+CSC - US plus $0.1 \mathrm{~kg}$ cotton seed cake; TS+CSC - TS plus $0.1 \mathrm{~kg}$ cotton seed cake

s.e.d. - standard error of differences of the means

${ }^{\mathrm{abc}}$ Values in row with similar superscripts do not differ $(\mathrm{P}>0.05)$.

The AN concentrations in ruminal fluid for all but the $\mathrm{H}$ diet were within the range of 40 to 250 $\mathrm{mg} / \mathrm{L}$, which was reported by Erdman et al. (1986) to be optimal for digestion depending on the potential digestibility of feed. Ruminal fluid AN concentration depends on quantity and degradability of $\mathrm{N}$ in ingested feed, the rate of incorporation of AN into microbial protein and rates of passage and absorption of AN from the rumen (Streeter \& Horn, 1984; Oosting, 1993). The lower ruminal fluid AN concentration for H was probably due to its lower $\mathrm{CP}$ content and high lignin content (Table 1). Some of the $\mathrm{N}$ was probably ligninbound and therefore unavailable to microorganisms.

Treatment of maize stover with urea increased $(\mathrm{P}<0.05)$ the AN concentration in rumen fluid and can be attributed to its increased $\mathrm{N}$ content (Table 1) and availability. This observation agrees with those of Tuen et al. (1991), Oosting (1993) and Manyuchi et al. (1994). The increase in AN concentration in ruminal fluid after urea treatment in the present study can be associated with increased digestibility of the treated stover (Table 2).

Cotton seed cake supplementation increased $(\mathrm{P}<0.05)$ AN concentration for $\mathrm{H}$ from 9 to $69 \mathrm{mg} / \mathrm{L}$ because of increased rate of $\mathrm{N}$ release from CSC. The AN concentration after CSC supplementation increased $(\mathrm{P}<0.05)$ for TS but not for US, probably due to inadequate ruminal AN production in relation to 
demand that resulted in increased efficiency of AN utilization and enhanced OM digestibility for the US diet. The result was an increase in VFA levels concurrent with AN release for US+CSC (Table 3 and Figure 2).

The parameter estimates and trends of ruminal fluid AN concentrations for the six experimental diets during the first six hours after feeding are presented in Table 4 and Figure 1 . The AN concentration for TS treatment increased up to four hours post feeding and then declined while those for $\mathrm{H}$ and US either remained unaltered or decreased with time during the first six hours after morning feeding. The increase in AN concentration in the TS diet was likely due to its higher content and faster release of N. It is possible that the AN from $\mathrm{H}$ and US treatments was released and utilized at a slower rate. Normally cell wall carbohydrates (hemicellulose and cellulose) become increasingly available 4-6 hours after feeding (Van Soest, 1994), and this may explain the eventual decline in AN concentration for TS due to its increased incorporation by microorganisms.

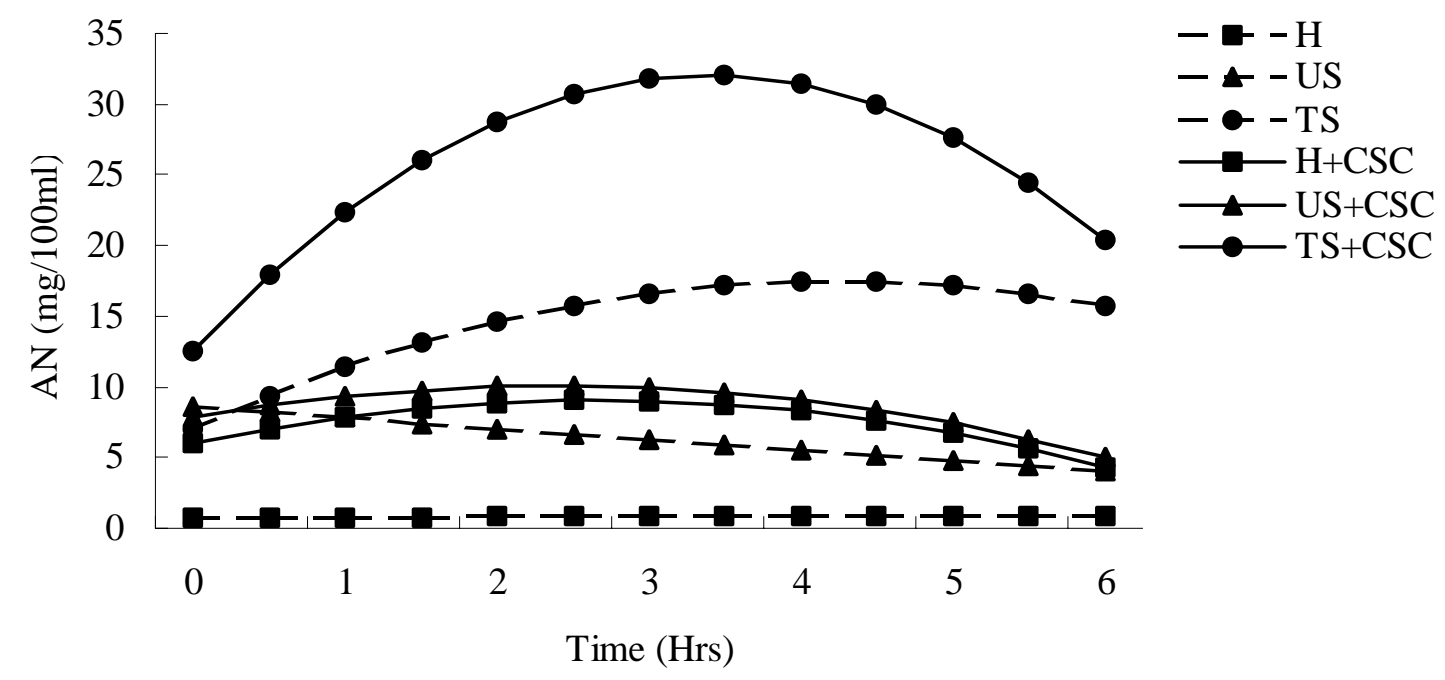

Figure 1 Changes in ammonia-nitrogen (AN) concentration in ruminal fluid of sheep in the six experimental diets during the first six hours after morning feeding ( $\mathrm{H}$ - hay; US - untreated maize stover; TS - urea treated maize stover; $\mathrm{H}+\mathrm{CSC}$ - $\mathrm{H}$ plus $0.1 \mathrm{~kg}$ cotton seed cake; US+CSC - US plus $0.1 \mathrm{~kg}$ cotton seed cake; TS+CSC - TS plus $0.1 \mathrm{~kg}$ cotton seed cake)

The AN levels in the ruminal fluid from the diets containing CSC (H+CSC, US+CSC and TS+CSC) initially increased and then declined (Figure1). Supplementing TS with CSC increased $(\mathrm{P}<0.05)$ AN concentrations compared to the effect on $\mathrm{H}$ and US (Table 4). Similar trends of AN concentration were reported by Oosting (1993) when he fed sheep on wheat straw supplemented with potato protein. The AN concentration for TS+CSC treatment increased up to around three hours post feeding and then declined sharply up to six hours post feeding (Figure1 and Table 4). A rapid increase of AN concentration is evidence of rapid production with inadequate use. Compensatory absorption through the rumen wall restores the equilibrium. Absorption of ammonia from the rumen increases with increasing ammonia concentration gradient between rumen and rumen wall cells (Oosting, 1993).

The molar proportions of acetate, propionate, butyrate, isobutyrate, valerate and isovalerate acids in ruminal fluid did not differ between diets $(\mathrm{P}>0.05)$. The molar proportions for acetate, propionate and butyrate varied from 47.8 to $56.4 \%, 12.5$ to $18.9 \%$ and 9.7 to $13.5 \%$, respectively. The fluid VFA concentrations in the fluid from the $\mathrm{H}, \mathrm{TS}, \mathrm{H}+\mathrm{CSC}$, and TS+CSC diets (Table 3) were within the normal range of 70-150 mmol/L (McDonald et al., 1995). The VFA concentration of US was below while that of US+CSC above this range. The concentration of VFA is regulated by production, absorption across the rumen wall and utilization by rumen microorganisms (Van Soest, 1994). Production of VFA depends on the availability of fermentable OM in the feed (Oosting, 1993). Organic matter digestibility for US (475 g/kg) was similar to that for $\mathrm{H}(488 \mathrm{~g} / \mathrm{kg})$ whose VFA concentration in the ruminal fluid was within the normal 
range. Organic matter digestibility for US+CSC (614 g/kg) was similar to that of TS+CSC $(668 \mathrm{~g} / \mathrm{kg})$ whose VFA concentration was also within the normal range. It is, therefore, difficult to explain from the experiment why VFA concentrations for US and US+CSC were respectively lower and higher than those normally observed. It could probably be due to variations in other parameters that determine VFA concentration like rumen fluid volume and rate of absorption. These parameters were not measured in the current study.

Table 4 Parameters, $a, b_{1}$ and $b_{2}$, obtained from regression equations fitted to changes in ammonianitrogen (AN) and volatile fatty acids (VFA) concentrations in ruminal fluid over time for the treatment diets during the first six hours after morning feeding

\begin{tabular}{|c|c|c|c|c|c|c|c|}
\hline \multirow[t]{2}{*}{ Item } & \multicolumn{6}{|c|}{ Diets } & \multirow[b]{2}{*}{ s.e.d. } \\
\hline & $\mathrm{H}$ & US & TS & $\mathrm{H}+\mathrm{CSC}$ & US+CSC & TS+CSC & \\
\hline \multicolumn{8}{|l|}{ AN } \\
\hline & $6.9^{\mathrm{a}}$ & $85.7^{\mathrm{e}}$ & $70.6^{\mathrm{C}}$ & $60.1^{\mathrm{b}}$ & $78.6^{\mathrm{d}}$ & $125.6^{\mathrm{f}}$ & 2.0 \\
\hline b & $0.08^{\mathrm{ab}}$ & $-0.77^{\mathrm{a}}$ & $4.93^{\mathrm{b}}$ & $2.29^{\mathrm{ab}}$ & $1.87^{\mathrm{ab}}$ & $11.51^{\mathrm{c}}$ & 2.5 \\
\hline 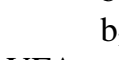 & $-0.01^{\mathrm{a}}$ & $0.004^{\mathrm{a}}$ & $-0.58^{\mathrm{a}}$ & $-0.43^{\mathrm{a}}$ & $-0.39^{\mathrm{a}}$ & $-1.70^{\mathrm{b}}$ & 0.42 \\
\hline \multicolumn{8}{|l|}{ VFA } \\
\hline b & $\begin{array}{l}24.4 \\
2.21^{\mathrm{ab}}\end{array}$ & $\begin{array}{c}56.1 \\
-1.75^{\mathrm{ab}}\end{array}$ & $\begin{array}{l}138.0 \\
-6.88^{\mathrm{a}}\end{array}$ & $\begin{array}{l}54.1 \\
1.54^{\mathrm{ab}}\end{array}$ & $\begin{array}{l}190.1 \\
2.18^{\text {ab }}\end{array}$ & $\begin{array}{r}4.2 .2 \\
4.88^{b}\end{array}$ & $\begin{array}{l}5.6 \\
4.8\end{array}$ \\
\hline b & $-0.08^{\mathrm{ab}}$ & $0.20^{\mathrm{ab}}$ & $1.03^{\mathrm{b}}$ & $-0.21^{\mathrm{ab}}$ & $-0.47^{\mathrm{a}}$ & $-0.83^{\mathrm{a}}$ & 0.73 \\
\hline
\end{tabular}

H- hay; US - untreated maize stover; TS - urea treated maize stover; H+CSC - H plus 0.1 kg cotton seed cake; US+CSC - US plus $0.1 \mathrm{~kg}$ cotton seed cake; TS+CSC - TS plus $0.1 \mathrm{~kg}$ cotton seed cake $\mathrm{a}$ - intercept; $\mathrm{b}_{1}$ and $\mathrm{b}_{2}$ - parameters describing the trend ${ }^{\text {abcdef }}$ Values in row with similar superscripts do not differ $(\mathrm{P}>0.05)$

Urea treatment of maize stover caused a moderate increase $(\mathrm{P}>0.05)$ in VFA concentration in the ruminal fluid, despite a significant increase in OM digestibility (Table 2). The VFA concentration in the US treatment increased $(\mathrm{P}<0.05)$ with CSC supplementation and was related to an increase in OM digestibility. Increased VFA concentration indicates increased microbial activity (Oosting, 1993) that is associated with increased utilization of AN. However, a non-significant increase in AN concentration in the ruminal fluid was observed after US supplementation with CSC (Table 3).

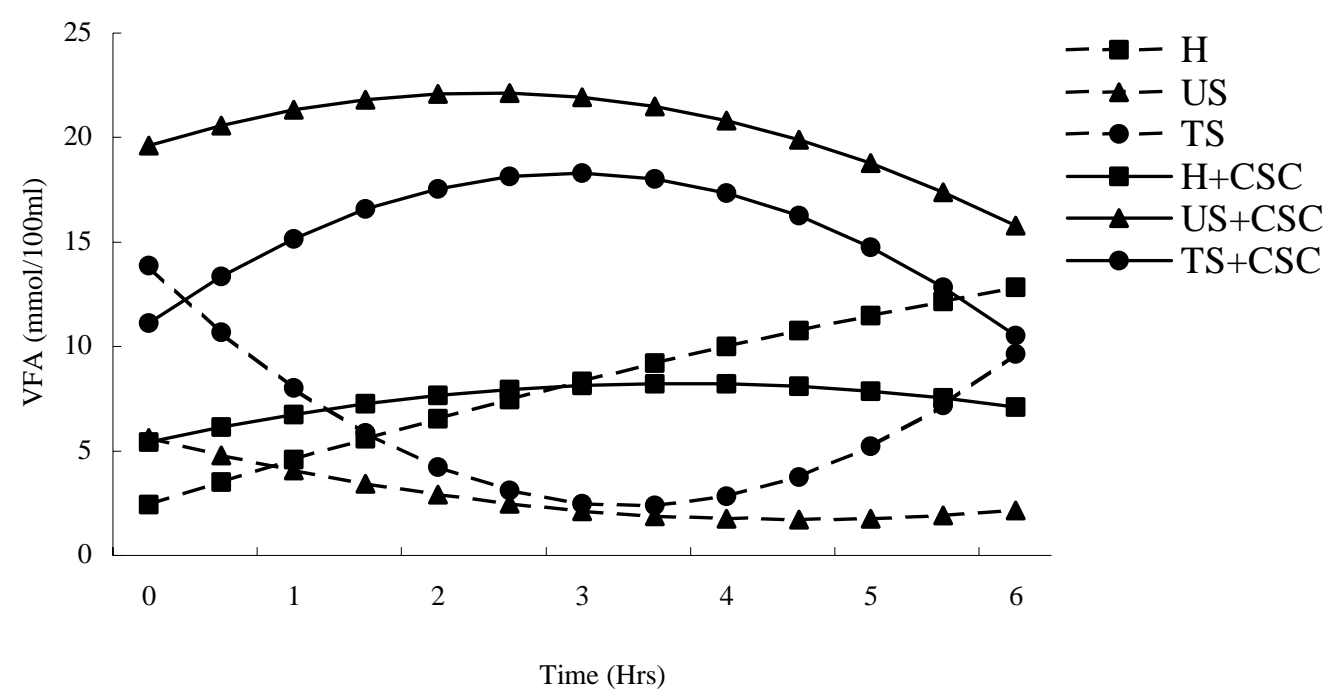

Figure 2 Changes in VFA concentration in ruminal fluid for the six experimental diets during the first six hours after morning feeding

( $\mathrm{H}$ - hay; US - untreated maize stover; TS - urea treated maize stover; $\mathrm{H}+\mathrm{CSC}$ - $\mathrm{H}$ plus $0.1 \mathrm{~kg}$ cotton seed cake; US+CSC - US plus $0.1 \mathrm{~kg}$ cotton seed cake; TS+CSC - TS plus $0.1 \mathrm{~kg}$ cotton seed cake)

Trends of rumen fluid VFA concentrations for the six experimental diets during the first six hours after feeding are presented in Figure 2. The VFA concentration of the $\mathrm{H}$ treatment increased while that of the US 
and TS treatments decreased with time after feeding. However, the parameters describing the trends were similar ( $>$ > 0.05; Table 4). Poor quality roughages normally take longer before significant degradation takes place. The concentration of VFA for the supplemented diets increased up to three hours post-feeding and then declined. The trend for all diets except US+CSC tended to be similar (Table 4).

The molar proportions of acetate, propionate, butyrate, isobutyrate, valerate and isovalerate acids in the ruminal fluid did not differ between diets $(\mathrm{P}>0.05)$. The molar proportions for acetate, propionate and butyrate varied from 47.8 to $56.4 \%, 12.5$ to $18.9 \%$ and 9.7 to $13.5 \%$, respectively.

\section{Conclusion}

Urea treatment of maize stover increased CP and lowered NDF content, and increased the DM, OM, and CP digestibility. This coupled with the slight increase in intake would lead to improved utilization of the stover. Supplementation of stover with cotton seed cake improved dry matter intake, OM and CP digestibility with a resultant increase in VFA production, all indicative of better utilization. Inclusion of cotton seed cake in urea treated maize stover had no effect on intake and nutrient digestibility and resulted in a large increase in AN in the ruminal fluid, an indication of inefficient utilization of nitrogen or excess degradable nitrogen in the rumen. Treatment of maize stover with urea or supplementation with cotton seed cake led to improved utilization while it was not necessary to supplement urea treated maize stover with a protein source like cotton seed cake, unless accompanied with a readily fermentable energy source.

\section{Acknowledgements}

The authors wish to thank the Agricultural Research Fund (ARF) of Kenya Agricultural Research Institute (KARI) for their financial support to carry out the study.

\section{References}

Alayu, H., 1987. Evaluation of the nutritive value of urea treated and cotton seed cake supplemented wheat straw. MSc thesis, University of Nairobi, Kenya, 154 pp.

AOAC, 1998. Official methods of analysis (16th ed.). Association of Official Analytical Chemists, Washington D.C., USA.

Butterworth, M.H. \& Mosi, A., 1986. The intake and digestibility by sheep of oat straw and maize stover offered with different levels of noug (Guizotia abyssinica) meal. Anim. Feed Sci. Technol. 16, 99107.

Chandrasekharaiah, C., Reddy, M.R. \& Reddy, G.V.N., 1996. Effect of feeding urea treated maize stover on growth and nutrient utilization by sheep and goats. Small Rumin. Res. 22, 141-147.

Cronje, P.B. \& Weites E., 1990. Live mass, carcass and wool growth responses to supplementation of a roughage diet with sources of protein and energy in South African Mutton Merino Lambs. S. Afr. J. Anim. Sci. 20, 161-168.

Erdman, R.A., Proctor, G.H. \& Vandersall, J.H., 1986. Effects of rumen ammonia concentration on in situ rate and extent of digestion of feedstuffs. J. Dairy Sci. 69, 2312-2320.

Goering, H.K. \& Van Soest, P.J., 1970. Forage fibre analysis. Agricultural Handbook No. 379, Agricultural Research Services, U.S. Department of Agriculture.

ILRI (International Livestock Research Institute), 1997. Analytical methods for feeds, animal excrements and animal tissues. ILRI, Addis Ababa, Ethiopia. pp. 38-39.

Kiangi, E.M.F \& Kategile, J.A., 1981. Different sources of ammonia for improving the nutritive value of low quality roughages. Anim. Feed Sci.Technol. 6, 377-386.

Leng, R., 1999. Feeding strategies for improving milk production. In: Smallholder Dairying in the Tropics. Eds. Falvey, V. \& Chantalakhana, C., International Livestock Research Institute, Nairobi, Kenya. pp. 207-224.

Manyuchi, B., Mikayiri, S. \& Smith, T., 1994. Effect of treating or supplementing maize stover with urea on its utilization as feed for sheep and cattle. Anim. Feed Sci. Technol. 49, 11-23.

McDonald, P., Edwards, R.A. \& Greenhalgh, J.F., 1995. Animal Nutrition. (5th ed.). Longman Group (UK) LTD, Essex, UK. 607 pp.

Methu, J.N., 1998. Strategies for utilization of maize stover and thinnings as dry season feed for dairy cows in Kenya. PhD thesis, The University of Reading, UK. 298 pp. 
Oliveros, B.A, Britton, R.A. \& Klopfenstein, T.J., 1993. Ammonia and/or calcium hydroxide treatment of maize stover: intake, digestibility and digestion kinetics. Anim. Feed Sci.Technol. 44, 59-72.

Omore, A., McDaermott, J.J. \& Gitau, G.K., 1996. Factors influencing production in smallholder dairy farms in Central Kenya. In: Focus on Agricultural Research for Sustainable Development in a Changing Economic Environment. Eds. Fungoh, P.O. \& Mbadi, G.C.O., Proc. $5^{\text {th }}$ KARI Scientific Conf. KARI Headquarters, Nairobi, Kenya. pp. 370-380.

Oosting, S.J., 1993. Wheat straw as ruminant feed. Effect of supplementation and ammonia treatment on voluntary feed intake and nutrient availability. $\mathrm{PhD}$ thesis, Agricultural University of Wageningen, The Netherlands, 232 pp.

Ørskov, E.R. \& Grubb, D.A., 1978. Validation of new systems for protein evaluation in ruminants by testing the effect of urea supplementation on intake and digestibility of straw with or without sodium hydroxide treatment. J. Agric. Sci. 91, 483-486.

Osuji, P.O., Fernandez-Rivara \& Odenyo, A., 1995. Improving fibre utilization and protein supply in animals fed poor quality roughages: ILRI nutrition research and plans. In: Rumen Ecology Research Planning. Eds. Wallace, R.J. \& Lohlon-Kass, Proc. workshop held at ILRI Addis Ababa, Ethiopia, 13-18 March 1995. International Livestock Research Institute (ILRI), Kenya. pp. 1-24.

Preston, T.R., 1986. Strategies for optimizing the utilization of crop residues and agro-industrial by-products for livestock feeding in the tropics. In: Towards optimal feeding of agricultural by-products to livestock in Africa. Eds. Preston, T.R. \& Nuwanyakpa, M.Y. Proc. workshop held at the University of Alexandra, Egypt, October 1985, (ARNAB). ILCA, Addis Ababa, Ethiopia. pp. 145-166.

Preston, T.R., 1995. Tropical animal feeding. A manual for research workers. FAO Animal Production and Health Paper 126. FAO, Rome, Italy. pp. 207.

Sahnoune, S., Besle, J.M., Chenost, M., Jouany, J.P., \& Combes, D., 1991. Treatment of straw with urea. 1. Ureolysis in a low water medium. Anim. Feed Sci. Technol. 34, 75-93.

Shashi-Saijpaul, Makkar, G.S. \& Saijpaul, S., 1996. Digestibility and availability of nutrients from alkaline hydrogen peroxide treated wheat straw and maize stover in male buffalo calves. Ind. J. Anim. Nutr. 13, 57-62.

Stat View, 1986. The professional graphic statistics utility. Brain Power, Inc., Calabasas, CA.

Streeter, C.L. \& Horn, G.W., 1984. Effect of high moisture and dry ammoniation of wheat straw on its feeding value for lambs. J. Anim. Sci. 59, 559-566.

Theander, O., 1981. Chemical composition of roughages as related to alkali treatment. In: Utilization of low quality roughages in Africa. Eds. Kategile, J.A., Said, A.N. \& Sundstol, F., Proc. workshop held at Arusha, Tanzania, 18-22 January, 1981. Agricultural University of Norway (AUN), Agricultural Development Report 1, pp. 1-15.

Tuen, A.A., Dahan, M.M., Young, B.A. \& Vijchulata, P., 1991. Intake and digestion of urea treated, urea supplemented and untreated rice by goats. Anim. Feed Sci. Technol. 32, 333-340.

Undi, M., Kawonga, K.C. \& Musendo, R.M., 2001. Nutritive value of maize stover/pasture legume mixtures as dry season supplemetation for sheep. Small Rumin. Res. 40, 261-267.

Van Soest, J.P., 1994. Nutritional ecology of the ruminant. (2nd ed.). Cornell University Press, Ithaca, New York, USA. 